\title{
IN FLUENCE OF FILLING ON WATER UPTAKE OF FILMS BASED ON WATER-BORNE COATING MATERIALS
}

\author{
Ivan Kas'yanenko ${ }^{1}$, Halyna Neskorozhena', Viktor Kramarenko ${ }^{1,}$ *
}

https://doi.org/10.23939/chcht12.04.466

\begin{abstract}
The effect of filling on water uptake has been studied for coatings based on aqueous dispersion Acronal290D and pigment part consisting of titanium dioxide and calcium carbonate. It was found that an increase in the pigment volume concentration is accompanied by an increase in the rate of water absorption, but the maximum value of water uptake is characterized by a minimum near the critical pigment volume concentration. It was shown that at a low degree of filling of the films, water absorption is a long-term process, the kinetics of which can be described by superposition of two functions that take into account both the Fickian character of water diffusion and the relaxation process, associated with structural changes in the samples.
\end{abstract}

Keywords: water-borne coating materials, polymer films, filling, water uptake, diffusion coefficient, pigment volume concentration (PVC), critical pigment volume concentration (CPVC).

\section{Introduction}

Water-based coating materials occupy a dominant place in the total volume of paint products due to practically complete absence of organic solvents in their composition, fire safety in the process of painting works, and the possibility of application under the conditions of high humidity. As a consequence, the assortment of water-based materials is permanently expanding both due to the appearance of new types of dispersions and owing to variation of the composition of such materials.

It is noteworthy that by using various pigments and/or fillers and changing the degree of filling of aqueous dispersions it is possible to obtain coating materials with substantially different properties. Thus, the materials with low pigment volume concentration (PVC) and a high degree of grinding are characterized by high penetrating ability, which allows to use them as primers for strengthening of relatively weak substrates, as well as

\footnotetext{
${ }^{1}$ RNational Technical University "Kharkiv Polytechnic Institute",

2, Kyrpychova St., 61002 Kharkiv, Ukraine

kram.cap@gmail.com

(c) Kas'yanenko I., Neskorozhena H., Kramarenko V., 2018
}

azures and impregnation compositions for wood. On the contrary, the systems with high filling level, sometimes even exceeding the critical volume pigment concentration (CPVC), have successful balance of relatively high vapor permeability and low water permeability, required to achieve high durability of coatings for mineral substrates, which are regulated by international standards ISO 7783 [1] and EN 1062-3 [2] for facade materials.

It deserves attention that in contrast to solventborne systems, for which the typical decrease of permeability with PVC increasing to CPVC value [3], the filling effect for polymer aqueous dispersion is not unambiguous. Indeed, for hybrid systems and in case of nanofillers using, the effect of decreasing permeability is retained with PVC increasing $[4,5]$. However, an inverse situation can also be found in the literature, when silicon dioxide [6] and mixtures of titanium dioxide with talc [7] or calcium carbonate [8] are used as the fillers in waterbased systems.

It should be noted, that the standard practice for determining of vapor and water permeability parameters assumes a relatively short-term impact of moisture or water during the measurements. Nevertheless, under the real conditions of coatings operation, the direct contact with water can be quite long, depending on the architectural features of the structure, which causes interest for study of water absorption at long-term observations.

The second peculiarity, which deserves attention, is the long ago established fact [9] that for certain type of films obtained from polymer aqueous dispersions the water impact is characterized by spontaneous loss of transparency and whitening, which is usually associated with the presence of residual surfactants and water-soluble components in such materials [10]. Nevertheless, the mechanism of this effect remains debatable and is the subject of recent research [11-13].

The purpose of the present work is to study the water uptake of films based on styrene-acrylate latex Acronal 290D, depending on the filling level and the regime of preliminary conditioning, by analogy with the approach used earlier [8]. 


\section{Experimental}

\subsection{M aterials and Preparation of the Compositions}

Styrene-acrylate latex Acronal 290D (BASF) with $50 \mathrm{wt} \%$ of non-volatile matter and a polymer particle size of $100 \mathrm{~nm}$ was used as a binder. Titane dioxide Crimea TiOx-280 and calcium carbonate Turcarb TC-2 with 2.5:1 $(\mathrm{w} / \mathrm{w})$ ratio were used as a pigment part.

The standard technology of water-based paints preparation, the details of which are presented in [8], has been used in the process of preparation of compositions. At the first stage the pigment paste was prepared by grinding of pigment and filler mixture in aqueous solution of hydroxyethylcellulose (Natrosol HHR, HEC). Then, the calculated amounts of the pigment paste and binder were mixed with addition of associative thickener Acrysol RM-825 (hydrophobically modified polyethylene oxide urethane, HMPOU), antifoaming agent (BYK-037) and coalescent (Texanol).

Since the pigment concentration is expressed in volume parts and the equilibrium water uptake $Q_{\max }$ is represented as the mass content of water relative to the initial mass of the sample, Table 1 shows the calculated values of the mass content of polymer components and pigment in dry films for different PVC values.

\subsection{Sample Preparation}

The compositions were applied to flat polypropylene surfaces by using the applicator. After coatings formation at the temperature of $296 \pm 2 \mathrm{~K}$ and the relative humidity of $50 \pm 5 \%$, the free films were carefully separated from substrate, and the samples for measurements were cut out as squares of $40 \times 40 \mathrm{~mm}$. The film thickness was $0.130 \pm 0.015 \mathrm{~mm}$ and was verified for each sample with accuracy of $0.005 \mathrm{~mm}$. Two parallel measurements were used for each PVC value.

\subsection{Determination of the Equilibrium W ater Content and Diffusion Coefficient}

The use of room temperature for the coatings formation leaves obvious uncertainty as to the achievement of films properties corresponding to the equilibrium state, due to the relatively low coalescence rate, as well as the potential changes in properties, associated with coalescent evaporation and migration of other components in the coatings. As a consequence, the preconditioning of such samples suggests the use of 3 cycles of immersion of the samples in water for $24 \mathrm{~h}$ and subsequent drying within $24 \mathrm{~h}$ at $323 \mathrm{~K}$. According to [1, 2] such conditioning facilitates the rapid transfer of samples into a quasi-equilibrium state, due to the removal of the components, that under the real operating conditions can be removed within a long period of time.

At the first stage of the measurements, it seemed interesting to find out how the preconditioning cycles affect the change in mass of the samples in the soaking mode in water (absorption) and subsequent drying (desorption) for each cycle. The measurements for samples of series from S1 to S4 were carried out using analytical balances with the accuracy of $0.0001 \mathrm{~g}$. The calculations of the mass increase due to exposure to water $Q(24+)$ and the mass loss as a result of drying $Q(24-)$ were made by equations:

$$
\begin{aligned}
& Q(24+)=\left(\frac{m(24+)-m_{0}}{m_{0}}\right) \cdot 100 \% \\
& Q(24-)=\left(\frac{m_{0}-m(24-)}{m_{0}}\right) \cdot 100 \%
\end{aligned}
$$

where $m_{0}$ is the initial mass of the sample, $\mathrm{g} ; m(24+)$ is the sample mass after exposure in water within $24 \mathrm{~h}$, g; $m(24-)$ is the sample mass after drying at $323 \mathrm{~K}$ within $24 \mathrm{~h}, \mathrm{~g}$.

Table 1

Mass content of components in the films depending on PVC

\begin{tabular}{|c|c|c|c|c|}
\hline \multirow{2}{*}{ PVC, \% } & \multicolumn{4}{|c|}{ Mass content in dry film, \% } \\
\cline { 2 - 5 } & Acronal & HEC & HMPOU & Pigment \\
\hline 0 & 100 & 0 & 0 & 0 \\
\hline 10 & 71.055 & 0.127 & 0.059 & 58.759 \\
\hline 30 & 40.664 & 0.291 & 0.446 & 68.296 \\
\hline 40 & 30.791 & 0.346 & 0.623 & 72.350 \\
\hline 45 & 26.664 & 0.364 & 0.668 & 75.977 \\
\hline 50 & 22.973 & 0.382 & 0.709 & 79.236 \\
\hline 55 & 19.655 & 0.400 & 0.750 & 82.196 \\
\hline 60 & 16.637 & 0.418 & 0.814 & 87.332 \\
\hline
\end{tabular}


After the complete preconditioning mode was performed, the equilibrium water uptake and the diffusion coefficient were determined for the S-4 series samples according to the standard procedure [14]. The samples were immersed in distilled water at a fixed temperature. At certain time intervals $\tau_{i}$ the mass of samples $m_{i}$ was determined after taking out of the water and removing of the moisture excess by filter paper. The experiment lasted until the dependency reached a constant value of the mass $m_{\infty}$, and after that the obtained data were converted into variable values of water uptake $Q_{i}$ :

$$
Q_{i}=\left(\frac{m_{i}-m_{0}}{m_{0}}\right) \times 100 \%
$$

and the degree of water absorption $\alpha_{i}$ :

$$
\alpha_{i}=\left(\frac{m_{i}-m_{0}}{m_{\infty}-m_{0}}\right)
$$

where $m_{\infty}$ is the maximum mass of the sample after the dependency $m_{i}\left(\tau_{i}\right)$ reached its constant value.

It is easy to show that a simple relation must hold between the parameters $Q_{i}$ and $\alpha_{i}$ :

$$
Q_{i}=\alpha_{i}\left(\frac{m_{\infty}}{m_{0}}-1\right) \times 100 \%=\alpha_{i} \times Q_{\max }
$$

The equilibrium water content $Q_{\infty}(\%)$ was calculated from Eq. (3) by using the value $m_{\infty}$, and the diffusion coefficient $D$ for basic Eq. (6) was determined by the nonlinear regression method from $\alpha_{i}\left(\tau_{i}\right)$ dependency:

$$
\alpha_{i}=1-\frac{8}{\pi^{2}} \sum_{n=0}^{\infty} \frac{1}{(2 n+1)^{2}} \exp \left[-\frac{D(2 n+1)^{2} \pi^{2} \tau_{i}}{\delta^{2}}\right]
$$

where $\delta$ is the film thickness, $\mathrm{m}$.

Finally, for the situations of very rapid water absorption and a limited number of experimental values for PVC $>50 \%$, the apparent diffusion coefficient was determined from the simplified equation [14]:

$$
D_{a p p}=0.93 \frac{\delta^{2}}{\tau_{\infty}}
$$

where $\tau_{\infty}$ is the time of equilibrium saturation of the sample with water, $\mathrm{s}$.

\section{Results and Discussion}

\subsection{Theoretical Consideration}

The properties of coatings based on polymer aqueous dispersions significantly depend on the effectiveness of the coalescence process at the stage of film formation. Therefore, it seemed expedient to carry out theoretical calculations of the maximum water uptake for idealized structure of the composite, assuming that the polymer matrix is a continuous medium, and the pigment particles are impermeable to water absorption. Under this consideration according to [12], the water sorption is considered to be a process corresponding to mechanism 1 , i.e. the water dissolution directly in the polymer matrix.

The calculations have been performed by Van Krevelen's group contribution method [15] for the components presented in Table 1, using the following assumptions. The main binder was considered as a copolymer of styrene and butyl acrylate with molar ratio of 1:1 (designation $c o-S-B A)$. It was also taken into account that at synthesis of such copolymers by emulsion polymerization the acrylic acid in the amount of $2 \mathrm{wt} \%$ is usually used for electrostatic stabilization of dispersions [4, 10] (designation co-S-BA-AA). Moreover, the stabilization effect is greatly enhanced by the transfer of carboxyl groups to the ionic form, which further increases the hydrophilicity of the copolymer (designation co-S-BA-AAn).

Taking into account that the concentration of hydrophilic cellulose thickener and associative thickener increases with increase of PVC, the $Q_{\max }$ values for HEC and HMPOU were additionally calculated in accordance with the chemical structures presented in [16]. For the associative thickener, the $Q_{\max }$ value was determined for the smallest molecular weight of the polyethylene oxide chain $\left(10^{4} \mathrm{~g} / \mathrm{mol}\right)$, based on the maximum hydrophilicity of the latter. The results of the calculations are presented in Table 2.

The theoretical values of $Q_{\max }$ as PVC function for the investigated system have been determined on the basis of the data presented in Table 1 and Table 2 (Fig. 1).

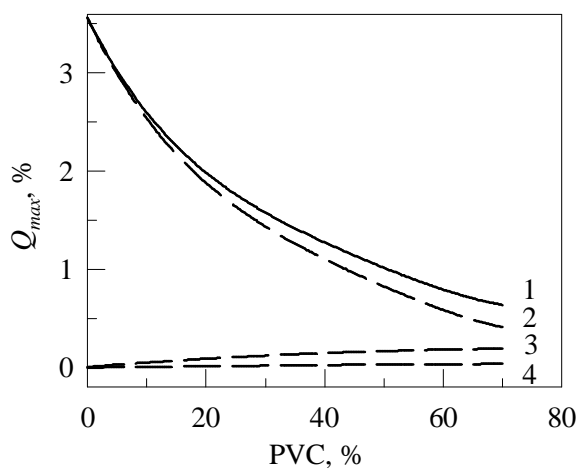

Fig. 1. Dependency of the calculated values of the equilibrium water uptake vs. PVC: total value (1); contribution of the binder (2); contribution of HEC (3) and contribution of HMPOU (4)

As follows from the calculated data, despite the very high hydrophilicity of HEC (Table 2), the dominant contribution to the expected value of water uptake is made by the content of the main binder, the concentration of which decreases with increasing of PVC. Therefore, the maximum expected value of $Q_{\max }$ should be equal to $3.56 \%$ (Table 2), as the value corresponding to unfilled copolymer film. 
Table 2

Theoretical values of equilibrium water uptake of individual polymer components

\begin{tabular}{|c|c|c|c|c|c|}
\hline Polymer & $c o$-S-BA & $c o$-S-BA-AA & $c o$-S-BA-AAn & HEC & HMPOU \\
\hline$Q_{\max } \%$ & 1.59 & 2.17 & 3.56 & 42.70 & 4.20 \\
\hline
\end{tabular}

\subsection{Preconditioning Effect}

Fig. 2 shows the dependencies that illustrate the samples behavior in the sorption-desorption regime at preconditioning stage. From these data it follows that for all the samples the water uptake values decrease as the number of preconditioning cycles increases. At the same time, this effect is the most pronounced for samples of S1 and S2 series with $\mathrm{PVC}<30 \%$. Against this background, the water uptake values for samples with PVC of 40-60\%, firstly, shows close absolute values at the level of $Q(24+)$ $\sim 5 \%$, and, secondly, the increase of conditioning cycles number is pronounced in the decrease of this parameter to a lesser extent. Similar behavior was observed earlier for the parameters of vapor and water permeability [8]. Also, worth noticing is the fact that the water uptake values, even for the S4 series samples, significantly exceed the calculated values of $Q_{\max }$ for all values of PVC (Fig. 1). This means that the mechanism of water sorption is related to a greater degree not to the water absorption of the polymer matrix itself, but to the process of water penetration into the elements of imperfect structure formed

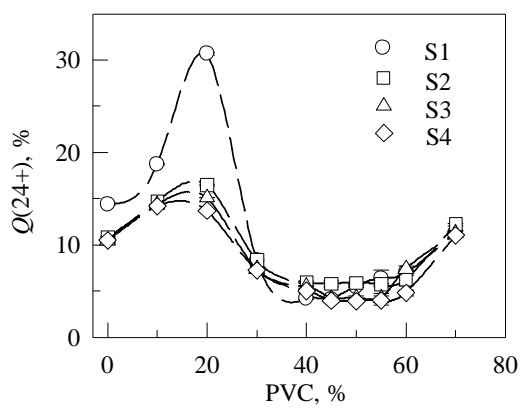

a) at the stage of coating formation, i.e. according to the mechanisms 2 and 3 [12]. Moreover, proceeding from the relatively low values of parameter $Q(24-) \sim 2 \%$ regardless of PVC (Fig. 2b), leaching of water-soluble components can not be the dominant cause of water absorption, especially considering the decrease of this parameter as the number of preconditioning cycles increases.

\subsection{PV C Effect}

Fig. 3 shows the water uptake for several samples with different filling degree. As follows from the presented data, an increase of pigment concentration leads to different behavior of the samples during storage in the water. Thus, at low PVC value the absorption of water occurs as very slow process, but with high values of equilibrium water uptake. For unfilled sample $(\mathrm{PVC}=0)$, the saturation process did not finish even at observation time duration of more than 150 days (see below). On the contrary, the water absorption is very fast process for high filling degree (Fig. 3b), but the equilibrium values $Q_{\max }$ coincide with the values of $Q(24+)$ for $\mathrm{S}-4$ series samples. Fig. 4 shows the concentration dependency of this parameter.

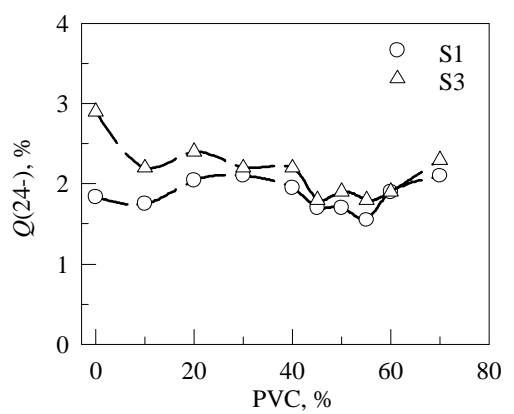

b)

Fig. 2. Effect of preconditioning on the water uptake $Q(24+)$ (a) and weight loss $Q(24-)$ (b) of the samples of different series

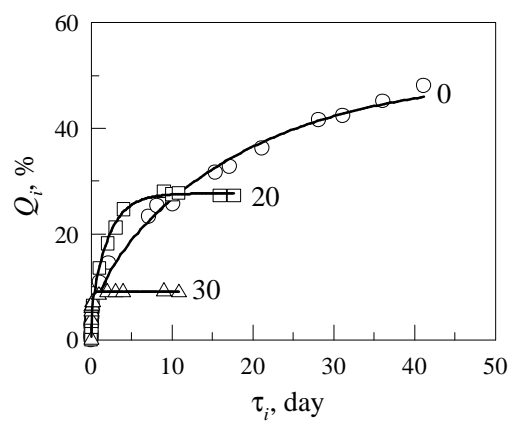

a)

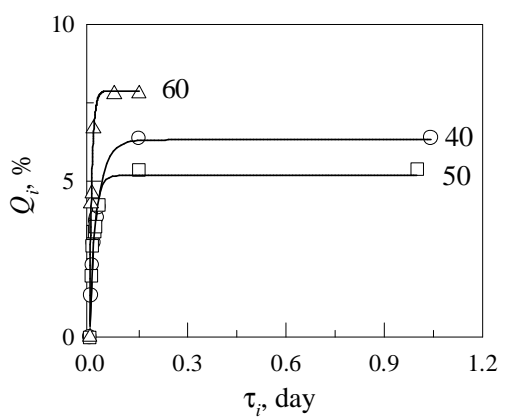

b)

Fig. 3. Water uptake of samples of S4 series with low (a) and high (b) PVC, the values of which are indicated near the curves 


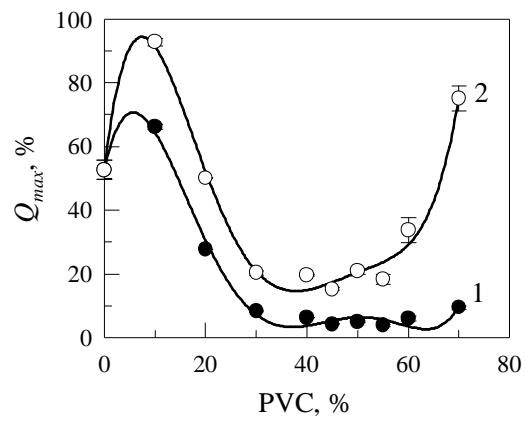

Fig. 4. PVC effect on equilibrium water absorption: experimental results (1) and recalculation data in terms of mass content of polymer in the films (2)

The obtained results indicate that, at low filling degree (PVC $<30 \%$ ), in addition to the capillary diffusion process, swelling of the samples occurs due to incomplete coalescence of the dispersion particles. When approaching the CPVC value $45-50 \%$ [8], this parameter becomes minimal and sharply increases, especially in the case of recalculation on the polymer content of the compositions (Fig.4, curve 2) when the CPVC value is exceeded, when the amount of binder begins to be insufficient to fill the volume between pigment particles.

The concentration dependency of the diffusion coefficient, determined from Eq. (6) is presented in Fig. 5.

From these data it follows that an increase in filling degree is accompanied by an increase of diffusion coefficient by 4 orders of magnitude when comparing the values of the boundary samples of the series. Thus, the filling in the system under consideration, on one hand, is the reason of capillaries formation through which diffusion of water molecules occurs, and this is in good agreement with the concentration dependencies of the vapor and the water permeability determined earlier [8]. However, at PVC $30 \%$ a peculiar framework begins to form due to the interaction of pigment particles,

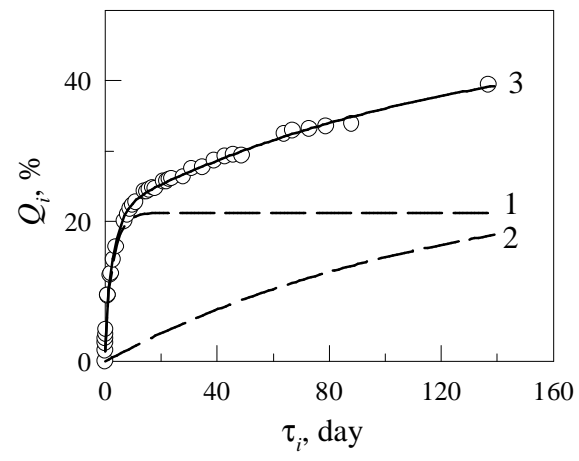

a)

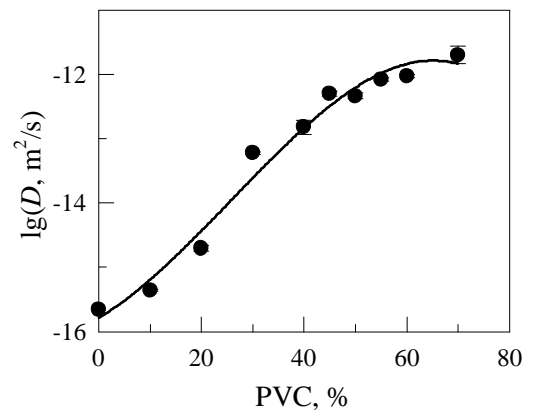

Fig. 5. PVC effect on diffusion coefficient

and this framework prevents the swelling effect, which is characteristic of the samples with low filling degree.

\subsection{W ater Uptake of U nfilled Films}

As it was already noted above, the behavior of latex films upon contact with water can be accompanied by a spontaneous process of whitening, and the mass increase of the sample can occur within long period of time. This is fully typical for the considered type of dispersion. Therefore, in order to expand the concept of water absorption mechanism for unfilled samples and to find the adequate mathematical description of kinetics of this process, free films were prepared according to the following formation mode of the coatings: treatment at $295 \mathrm{~K}-1 \mathrm{~h} ; 323 \mathrm{~K}-24 \mathrm{~h} ; 363 \mathrm{~K}-1 \mathrm{~h}$.

Since the minimum film formation temperature of the dispersion is $293 \mathrm{~K}$ and the glass transition temperature of the copolymer is $295.9 \mathrm{~K}$ [17], the use of elevated temperatures should ensure the maximum efficiency of the coalescence process. At the same time, the use of a low water temperature during the immersing should ensure the sorption process in the glassy state of polymer matrix. Fig. 6 shows the water uptake for the two measurement temperatures for unfilled films.

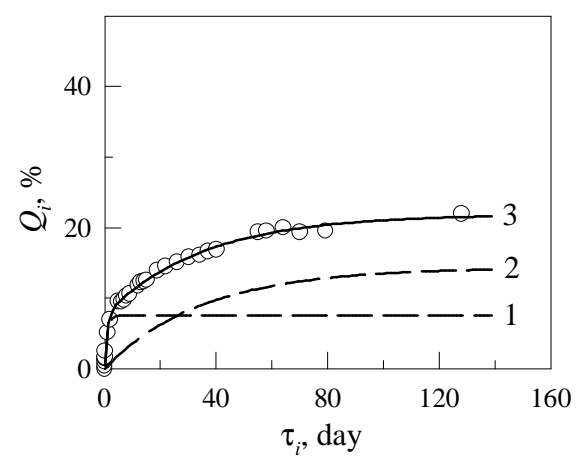

b)

Fig. 6. Water uptake of latex films at the temperature of $291 \pm 2 \mathrm{~K}$ (a) and $277 \pm 1 \mathrm{~K}$ (b).

The symbols show the experimental values. The dashed lines show the contributions of the diffusion (2) and the relaxation (3) dependencies. The solid line (1) is the resulting dependency 
As follows from the presented data, the decrease of exposure temperature is appropriately manifested at the decrease in the level of water uptake absolute values. However, even in the case of exposure to water with low temperature for 150 days the water absorption is not accompanied by the achievement of $Q_{i}$ constant value. At this, the experimentally achieved values also significantly exceed the value of $3.56 \%$ theoretically determined in Section 3.1 for unfilled copolymer.

According to the classification [3], such water absorption is considered as a combination of two processes, one of which corresponds to the Fickian mechanism of capillary permeability, while the second is a relatively slow relaxation process associated with structural transformations of the polymer under the water effect. A kinetic description of this two-stage sorption process was proposed by the authors [18] in the form of the superposition of two functions:

$$
Q_{i}=Q_{i}(F)+Q_{i}(R)
$$

where $Q_{i}(F)$ is sorbent absorption, occurring according to the Fickian mechanism (Eqs. (5) and (6)); $Q_{i}(R)$ is sorbent adsorption, associated with relaxation processes, governed by the first-order kinetics:

$$
Q_{i}(R)=\sum_{j=1}^{m} Q_{\infty, j}(R)\left[1-\exp \left(-k_{j} \tau_{i}\right]\right.
$$

where $k_{j}$ is the constant of the relaxation process rate.

Thus, with a restriction of the number of the summands $j=1$, the resulting equation takes the form:

$$
\begin{aligned}
& Q_{i}=Q_{\infty}(F)\left(1-\frac{8}{\pi^{2}} \sum_{n=0}^{\infty} \frac{1}{(2 n+1)^{2}} \cdot\right. \\
& \left.\cdot \exp \left[-\frac{D(2 n+1)^{2} \pi^{2} \tau_{i}}{\delta^{2}}\right]\right)+Q_{\infty}(R)\left[1-\exp \left(-k \tau_{i}\right]\right.
\end{aligned}
$$

where $Q_{\infty}(F)$ and $Q_{\infty}(R)$ are the limiting values of the water uptake at the stage of Fickian and relaxation sorption.

The results of fitting by Eq. (10) are shown in Fig. 6 in the form of the corresponding contributions (dashed lines) and resulting curves (solid lines). The values of the fitting parameters are presented in Table 3.

Table 3

Dependency of fitting parameters on the temperature

\begin{tabular}{|c|c|c|c|c|}
\hline$T, \mathrm{~K}$ & $Q_{\infty}(F), \%$ & $D \cdot 10^{15}, \mathrm{~m}^{2} / \mathrm{s}$ & $Q_{\infty}(R), \%$ & $k \cdot 10^{7}, \mathrm{~s}^{-1}$ \\
\hline 291 & 21.2 & 8.3 & 26.5 & 0.95 \\
\hline 277 & 7.5 & 17.0 & 14.4 & 3.30 \\
\hline
\end{tabular}

From the obtained results it follows that the use of superpositions of two functions does perfectly describe the experimental dependencies with qualitative agreement that the general process of water absorption can be considered as a combination of relatively fast Fickian diffusion process and relatively slow relaxation process described by the kinetic parameter $k$. However, the dependency of these parameters on the temperature indicates that they should be regarded exclusively as fitting parameters, since a significant increasing in the asymptotic characteristics of $Q_{\infty}(F)$ and $Q_{\infty}(R)$ with temperature increasing is mathematically compensated by decreasing of parameters $D$ and $k$ (Table 3 ).

\section{Conclusions}

The water uptake of films based on filled compositions of aqueous dispersion of styrene-acrylate copolymer indicates a significant effect of the filling level on the behavior of parameters characterizing the process of water sorption. It is demonstrated that PVC increasing leads to appropriate increase of diffusion coefficient, the value of which increases by more than 4 orders of magnitude when comparing the samples with the PVC $>$ CPVC relative to the unfilled sample. However, the values of equilibrium water absorption show an extreme dependency with a minimum near CPVC value. Comparison of the absolute and the theoretical values of the maximum water uptake, as well as long-term water sorption for unfilled sample and samples with PVC $<30 \%$, indicates that for the considered type of dispersion the penetration of water can not be related to its direct dissolution in the polymer matrix, but rather it occurs due to incompleteness of coalescence process at the stage of film formation. Increasing the filling degree leads to decreasing of this effect.

\section{References}

[1] ISO 7783:2011 Paints and varnishes: Determination of watervapour transmission properties.

[2] EN 1062-3:2008 Paints and varnishes: Coating materials and coating systems for exterior masonry and concrete. Part 3:

Determination of liquid water permeability.

[3] Wel G., Adan O.: Prog. Org. Coat., 1999, 37, 1.

https://doi.org/10.1016/S0300-9440(99)00058-2

[4] Zhu A., Cai A., Yu Z., Zhou W.: J. Coll. Inter. Sci., 2008, 322, 51. https://doi.org/10.1016/j.jcis.2008.02.014

[5] Maksimov R., Gaidukovs S., Zicans J., Jansons J.: Mech. Compos. Mater., 2008, 44, 505.

https://link.springer.com/article/10.1007/s11029-008-9041-x

[6] Donkers P., Huinink H., Erich S. et al.: Prog. Org. Coat., 2013, 76, 60. https://doi.org/10.1016/j.porgcoat.2012.08.011

[7] Jubete E., Liauw C., Allen N.: Prog. Org. Coat., 2007, 59, 126. https://doi.org/10.1016/j.porgcoat.2007.01.021 
[8] Kas'yanenko I., Kramarenko V.: Vopr. Khimii ta Khim. Tech., 2016, 2, 68. http://nbuv.gov.ua/UJRN/Vchem_2016_2_14

[9] Agarwal N., Farris R.: J. Appl. Polym. Sci., 1999, 72, 1407. https://doi.org/10.1002/(SICI)1097-

4628(19990613)72:11<1407::AID-APP4>3.0.CO;2-5

[10] Snuparek J., Bidman A., Hantus J., Haikova B.: J. Appl. Polym. Sci., 1983, 28, 1421. https://doi.org/10.1002/app.1983.070280415

[11] Butler L., Fellows C., Gilbert R.: J. Appl. Polym. Sci., 2004, 92, 1813. https://doi.org/10.1002/app.20150

[12] Liu Y., Gajewicz A., Rodin V. et al.: J. Polym. Sci. Polym. Phys., 2016, 54, 1658. https://doi.org/10.1002/polb.24070

[11] Jiang B., Tsavalas J., Sundberg D.: Prog. Org. Coat., 2017, 105, 56. https://doi.org/10.1016/j.porgcoat.2016.12.027

[12] ASTM D 5229/D 5229M-92 (Reapproved 2004) Standard test method for moisture absorption properties and equilibrium conditioning of polymer matrix composite materials.

[13] Van Krevelen D., Te Nijenhuis K.: Properties of Polymers. Elsevier, Amsterdam 2009.

[14] Bieleman J.: Additives for Coatings, WILEY-VCH Verlag GmbH, Weinheim 2000.

[15] Maksimov R., Gaidukovs S., Kalnins M. et al.: Mech. Compos. Mater., 2006, 42, 45. https://link.springer.com/article/10.1007/s11029006-0015-6

[16] Berens A., Hopfenberg H.: Polymer, 1978, 19, 489. https://doi.org/10.1016/0032-3861(78)90269-0

Received: September 14, 2017 / Revised: November 03, 2017 / Accepted: March 02, 2018

\section{ВПЛИВ НАПОВНЕННЯ НА ВОДОПОГЛИНАННЯ ПЛІВОК НА ОСНОВІ ВОДНО-ДИСПЕРСІЙНИХ ЛАКОФАРБОВИХ МАТЕРІАЛІВ}

\begin{abstract}
Анотація. Вивчено ефект наповнення на водопоглинання плівок на основі водної дисперсії Акронал-290Д та пігментної частини, щуо містить діоксид титану та карбонат кальйію. Встановлено, щзо збільшення об'ємної концентрації пігменту супроводжується збільшенням швидкості абсорбиії води, однак максимальне значення водопоглинання характеризується мінімумом в діпазоні критичної об'ємноі концентрації пігменту. Показано, щуо у разі низького ступеня наповнення плівок поглинання води є довготривалим процесом, кінетику якого можна представити суперпозицією двох функцій, щзо враховують як фіковський характер дифузї води, так й релаксаиійний процес, пов'язаний із структурними змінами у зразках.
\end{abstract}

Ключові слова: водно-дисперсійні лакофарбові матеріали, полімерні плівки, наповнення, водопоглинання, коефіијєнт дифузії, об’ємна концентрація пігменту (ОКП), критична об'ємна концентрачія пігменту (КОКП). 